\title{
Editorial
}

In the years after the fall of communist governments in Central, Eastern, and Southeastern Europe (CESEE), a flood of memoir literature began to fill bookstores around the region. Some of these books were newly written, others had been composed long ago but could not be published during the socialist period. Alongside this rush of published work, historians and anthropologists began numerous oral history projects devoted to recording ordinary people's experiences of state socialism. This need to narrate one's own past and capture the memories of those who witnessed the tragedies of the twentieth century continues to the present day. The turn to autobiography and personal narrative inspired the theme section in this issue of Aspasia: women's autobiographical writing and correspondence.

The authors in this section look at such texts in an array of historical settings. The first two articles examine women's autobiographical writing in the second half of the nineteenth century. Eve Annuk analyzes the work of Estonia's first feminist, the educator and journalist Lilli Suburg. The pioneering Suburg was harshly criticized for starting a magazine with the goal of educating women about nationalism and feminism in the 1880s - a time when most Estonians thought women's magazines should only publish articles about sewing and cooking. Annuk argues that Suburg began to use the techniques of autobiographical writing in all of her published work as a way of making her feminist ideas more acceptable. This "autobiographical strategy" allowed Suburg to publish radical ideas in a personal form. Alexandra Popoff compares two different autobiographical strategies by examining the memoirs of Sophia Tolstaia and Anna Dostoevskaia, the wives of two of Russia's most famous authors. Dostoevskaia, Popoff claims, wrote her autobiography in order to burnish her husband's reputation. Tolstaia, on the other hand, wanted to rehabilitate herself. She argued against Tolstoy's unflattering characterization of her, declaring that she had only done what was necessary to look after her children and her husband. Her controversial interpretation of her own life, Popoff argues, was the reason her Moia zhizn' (My life) was not published until 2010.

The next two articles in this section examine women's written memories of epochal moments in the Soviet past: the Holodomor (or Great Famine) that convulsed Ukraine in the aftermath of forced collectivization and the experience of women soldiers during World War II. In her article, Oksana Kis uses memoirs published since 1991 to excavate the gendered dimensions of the experience of the Holodomor. Writing with great sensitivity, Kis wants to see women as more than the passive victims of famine. While most did die of starvation, they actively resisted their fate in a variety of ways, 
some admirable and some not. Kis argues that while the experience of the famine was gendered, a consideration of the full spectrum of women's actions challenges the idea of an essentialist maternal instinct or sense of feminine solidarity. Finally, Adrienne Harris analyzes the poetry of Russian Iulia Drunina as a form of autobiographical narrative. Drunina's experience at the front as a medic during World War II shaped the rest of her life. Her poems explored the complexity of her identity as a woman and a soldier, and later a veteran. Drunina was not a dissident (she participated in the attempted August 1991 coup and killed herself when it failed), but her poems challenged the official image of the soldier as male. In her latest poems, gender moved more to the background as she explored the alienation of all veterans in a society that no longer seemed to appreciate their sacrifice for the Soviet state.

We then have two general articles. Orsolya Kereszty examines the Hungarian journal A Nó és a Társadalom (Woman and society), published from 1907 to 1913. Like Estonia's Lilli Suburg, the women who published A Nó és a Társadalom-most prominently editor Róza Schwimmer - wanted to use the journal to educate their readers about feminist ideas, particularly suffrage and women's employment. Kereszty gives us a brief history of the journal and then concentrates on its attempts to inform readers about the activities of the international women's movement. Then Alina Haliliuc returns us to the subject of memory by giving us a tour of the Museum of the Victims of Communism and of the Resistance in Sighet, Romania. She shows how the museum privileges a particular reading of the socialist past, one in which women's experiences are effectively erased from the history of resistance in communist Romania. Haliliuc argues that the museum renders specifically female experiences, like having an illegal abortion during the Ceauşescu regime, "unmemorable," unworthy of recollection and devoid of historical significance.

In this issue we present the continuation of a fascinating forum on women's and gender history in CESEE, "Clio on the Margins," edited by Krassimira Daskalova (the first five essays appeared in Aspasia [volume 6]). The eight essays in this section provide a comprehensive look at the state of the field of women's and gender history in Albania, Bulgaria, Croatia, Greece, Hungary, Lithuania, Poland, and Russia. Each is an invaluable resource for scholars around the world; the authors describe the development of women's and gender history in their country, consider how research questions, topics, and methodologies have changed over time, list key works and authors, and provide information about how well (or how poorly) women's and gender history is represented in university courses and elementary school textbooks. A number of the authors make the point that this kind of history is not simply a Western import into CESEE. During the socialist period, some worthy scholarship was being done (for example in Hungary, Lithuania, and Croatia) or the desire to do it was there, even if conditions did not always allow for it to happen (e.g., in Russia). The 1990s did bring significant changes (as they also did in the West), including new areas of research, such as the history of "bourgeois" women's organizations, the history of everyday life, cultural history, and the history of sexuality; as well as new approaches, including poststructuralist methodologies, discursive analysis, or the practice of oral history. Looking at the essays as a whole, we can see that Clio is often unfortunately still very much on the margins in CESEE, in some countries more than others. But there is also 
much to be positive about-women's and gender history is a vibrant and growing field in the region.

We conclude with two book review essays, twenty book reviews, and a conference report. For their help with volume 7, we would like to thank our peer reviewers for their expert assistance and our Editorial Board for their support. Special thanks go to Sharon Kowalsky and Rochelle Ruthchild for their superb editing assistance with the forum and the book reviews, and to Jessica Herzog for being a wonderfully capable editorial assistant.

The editors welcome contributions to Aspasia in any area of women's and gender history in CESEE on an ongoing basis. Information for potential contributors can be found on the inside back cover of this volume. For more information about Aspasia, please visit http://journals.berghahnbooks.com/asp/.

\section{Melissa Feinberg}

